\title{
AN INQUIRY INTO THE USE AND MEANING OF THE FORMS "EOHKE(N) AND OHKE(N) IN THE ILIAD: SYNTAX AND SEMANTICS
}

Keywords: augment, Homeric Greek morpho-syntax, injunctive, textual criticism

\begin{abstract}
In this article, I discuss the use and absence of the augment in the $3^{\text {rd }}$ singular forms $\ddot{\varepsilon} \theta \eta \kappa \varepsilon(v)$ and $\theta \tilde{\eta} \kappa \varepsilon(v)$ in the Iliad. In the previous article (De Decker 2020), I explained why I chose this corpus and determined the value of the different forms. Here I proceed to the actual analysis of the forms: do they confirm the previous syntactic and semantic observations that have been made for the use and absence of the augment (the clitic rule by Drewitt and Beck, the reduction rule by Kiparsky and the distinctions: speech versus narrative, foreground versus background and remote versus recent past)? ${ }^{1}$
\end{abstract}

\section{The syntactic factors}

\subsection{Drewitt-Beck's clitic rule}

It has been argued in the past that a past tense form followed by a $2^{\text {nd }}$ position clitic or a postpositive (enclitics and words that cannot be put in the beginning of a sentence) is generally unaugmented. This was first noted by Drewitt (1912b: 104, 1913: 350) and was expanded to the entire Homeric corpus by Beck (1919). ${ }^{2}$ The figures of the Iliad overall confirm this.

The acknowledgements are the same as in De Decker (2020).

2 Beck specifically linked this phenomenon and the placement of the 'Wackernagel clitics'. The rule is therefore best called 'Drewitt-Beck's Rule'. See also Marzullo (1952: 415), Bottin (1969: 99-102), Rosén (1973: 316-320), Bakker (1999: 53-54), Mumm (2004: \$5.3), De Lamberterie 


\begin{tabular}{|c|c|c|c|c|c|}
\hline 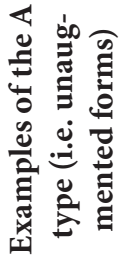 & 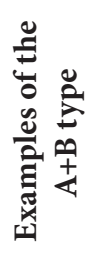 & 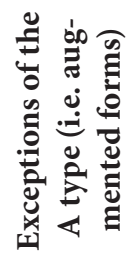 & 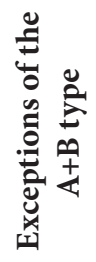 & 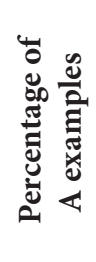 & 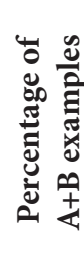 \\
\hline 53 & 54 & 12 & 14 & 82 & 79 \\
\hline 595 & 612 & 90 & 105 & 87 & 85 \\
\hline 28 & 28 & 5 & 5 & 85 & 85 \\
\hline 676 & 694 & 107 & 124 & 86 & 85 \\
\hline
\end{tabular}

In our corpus here we only find one example (that confirms the rule):

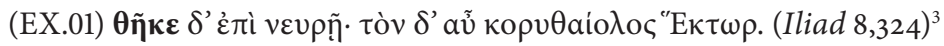

'He put it (sc. the arrow) on the bowstring, but then Hektor with the flashing helmet (hit) him.'4

In this verse, $\theta \tilde{\eta} \kappa \varepsilon$ is followed by $\delta$, which is a word that cannot appear at the beginning of the sentence, and therefore, the unaugmented form is used.

\subsection{Kiparsky's reduction rule}

Kiparsky (1968) argued that in PIE in a sequence of marked forms only the first one was marked and the others appeared in the neutral form: ${ }^{5}$ in a sequence of past tense forms only the first one was put in the indicative (with augment in Indo-Iranian and Greek) and the others following it in the injunctive, as this form was both tenseless and moodless. In epic Greek, an unaugmented verb form often appears when it is coordinated with a preceding augmented verb form by the connecting particles $\kappa a i ́, i \delta \dot{\varepsilon}, \tau \varepsilon, a ̈ \mu \alpha \tau \varepsilon, \tau \varepsilon \kappa a i$, and $\delta \dot{\varepsilon}$. This is called conjunction reduction (Kiparsky 1968; Fortson 2004: 140; Clackson 2007: 132; Luraghi 2014), although markedness reduction might be a better term. Kiparsky himself argued that the rule was absolute, but that many examples of it were obscured by the transmission; for Vedic, he explicitly ruled out that the injunctive could be used to mention

(2007: 53), García-Ramón (2012: B.2.3), De Decker (2015a: 56, 2015b: 249-250, 312, 2016a: 56-59, 2017: 79, 128-129), Hajnal (2016a: 13, 2016b: 446-447), Rodeghiero (2017: 634).

3 In what follows, augmented forms will be underlined and unaugmented forms will be put in bold face.

4 As was stated before, all translations are my own, unless stated otherwise.

5 Kiparsky expanded this in 2005 (discussing Hoffmann 1967), but the basic ideas of 1968 remained the same. See Hajnal (1990: 54-55, 2016a: 13, 2016b: 447-448), Szemerényi (1990: 282-284, 1996: 265-266), Pagniello (2002: 8-17), García-Ramón (2012: §B.2), Luraghi (2014) and De Decker (2015a: 57-59, 2015b: 250-254, 2016a: 58-71, 2017: 83-84, 130-135). 
events, as Hoffmann (1967) had argued, ${ }^{6}$ because such a "memorative" was typologically rare, if not non-existent. ${ }^{7}$ Levin (1969), who agreed with Kiparsky, noted that in many instances either the reduction did not occur or the augmented form was preceded by an unaugmented one; in addition, there were several passages in which only unaugmented forms were found. Earlier researches revealed that this is not a strict rule, but only a tendency: in Hesiod and Iliad 1 and 6, there were more unaugmented forms that followed an augmented form than augmented forms, but there will still be a considerable number of exceptions (De Decker 2016a: 58-71 for Hesiod; 2016b: 286-288 for Iliad 6; 2017: 130-135 for Iliad 1). An analysis of the data in the Iliad gives the following picture:
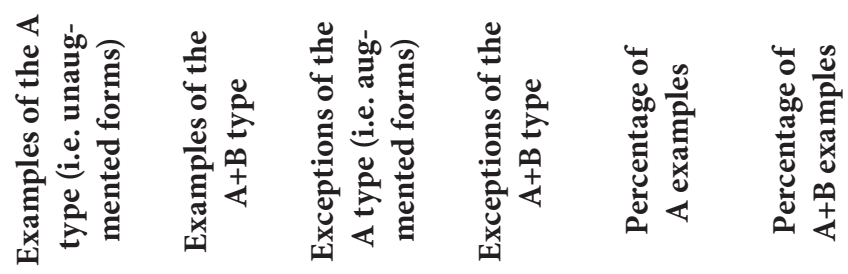

\begin{tabular}{lrrrrrr}
\hline Speeches & 441 & 513 & 328 & 530 & 57 & 49 \\
Narrative & 2479 & 3118 & 968 & 1693 & 72 & 65 \\
Speech introductions & 35 & 40 & 6 & 16 & 85 & 71 \\
Overall figures & 2955 & 3671 & 1302 & 2239 & 69 & 62
\end{tabular}

We note that especially in speeches the number of exceptions is particularly high, which indeed raises the issue if this rule is a rule at all. Space constraints prevent me from addressing the question in detail here, but given the fact that there are other reductions such as the use of the plural after having used the dual already, ${ }^{8}$ or the simplex after the compound form had appeared already, ${ }^{9}$ one could reasonably assume that there must have been some kind of constraint against using the

6 He used the term Memorativ.

7 Kiparsky (2005: \$1): “There seem to be no languages with a mood whose function is 'mentioning' or 'reminding'". See also Kloekhorst (2017: 300). I address this later on.

8 This analysis goes back to Wilhelm von Humboldt in 1827, quoted in Strunk (1975: 237) and Viti (2011: 602). Strunk (1975: 234-239) provided an analysis of Homeric and Attic (Xenophontic) instances to show that Greek did not need to mark the dual more than once. See Strunk (1975: 234-239), Fritz (2011: 50-51, with reference to Kiparsky 1968 and Strunk 1975), Viti (2011: 598-604, with reference to Corbett 2000: 14) and De Decker (2015b: 158-159) for the reduction in the dual and De Decker (2017: 132-134) for the instances of Iliad 1. For typological parallels, see Corbett (2000: 14, 42-50), but this reduction was not discussed in Cysouw (2011) or Moravcsik (2017).

Some examples of this reduction are Iliad 1,304-305; 1,328-329; 1,332-333; 6,233; 16,475; 22,160-161; 24,97-98; 24,711-712; Odyssey 22,114-115; 22,187-193; 22,201-203; HH 2,379-380; $4,503-505$.

9 Wackernagel (1924: 177); Clausen (1955: 49-51): "a Greek or Latin author sometimes reiterates a compound verb, either immediately or at a brief interval, in its simple form with the same 
same marked form too often in one series and I would argue that the reduction was restricted to actions within the same domain (e.g. the process of preparing a feast, the act of speaking, the act of recognizing someone, etc.), ${ }^{10}$ and that the use of augmented and unaugmented forms besides one another was not a random poetic choice, but a relic from the period in which this constraint was still operative.

In the corpus under investigation this rule in its strictest formulation (as Kiparsky seems to have done) does not operate: 24 examples that confirm the rule (of which 19 are of the type A), ${ }^{11}$ but there are 32 forms that contradict the observation (of which 23 are of the type A). ${ }^{12}$ I now give one example in favour and one against it (the augmented forms are underlined while the unaugmented ones are set in bold face and the metrically insecure forms are italicized; italicized forms that are underlined indicate forms that are metrically insecure, but in which internal reconstruction makes the augment preferred; italicized forms that are put in bold face indicate forms that are metrically insecure, but in which internal reconstruction makes the absence of the augment preferred):

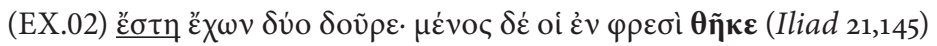

'He stood (in front of the river) with two spears in his hand and in his mind he (sc. Xanthos) had breathed courage.'

The verb form $\theta \tilde{\eta} \kappa \varepsilon$ is unaugmented, because it is preceded by the augmented है $\sigma \tau \eta$. There are also exceptions, as can be seen below.

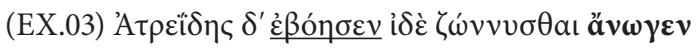

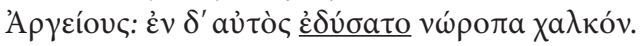

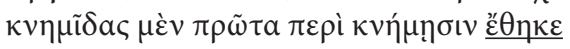

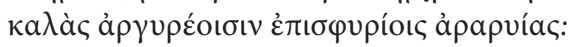

(Iliad 11,15-18)

'The son of Atreus shouted loudly and ordered the Argives to gird themselves. He himself put on the shining bronze. First, he placed his beautiful shin pads around his legs, assembled out of beautiful ankle pieces.'

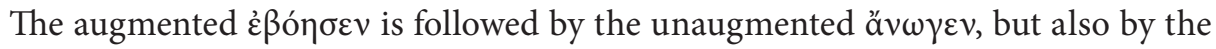

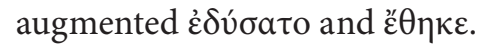

Sometimes, rules 1.1 and 1.2 operate simultaneously, as can be seen in the following instance (that had been discussed briefly before):

meaning"; Watkins (1967); Dubois (1986: 217-218 for the phenomenon in the Greek dialects). Dunkel (1978) was sceptical, but Patri (2007) showed that this rule was Indo-European after all.

10 This was described by Meillet (1913: 115-116) for Armenian and expanded to the other languages with an augment by De Lamberterie (2007: 39, 45).

${ }_{11}$ The metrically secure instances are Iliad 2,318; 6,303; 8,218; 8,324; 9,460; 10,46; 10,571; 12,399; 18,$375 ; 18,476 ; 18,615 ; 21,145 ; 23,263 ; 23,700 ; 23,748 ; 23,750 ; 23,826 ; 23,886 ; 24,101$ and the other instances are 9,$547 ; 10,466 ; 23,269 ; 23,653 ; 24,538$.

12 The instances are Iliad 2,319; 3,330; 3,336; 6,139; 9,483; 10,257; 10,261; 11,17; 15,480; 16,137; 17,569; 19,$369 ; 20,324 ; 21,82 ; 22,368 ; 23,265 ; 23,270 ; 23,382 ; 23,400 ; 23,406 ; 23,527 ; 23,568 ; 23,704$ and the other instances are 9,$207 ; 12,450 ; 19,407 ; 21,172 ; 21,524 ; 21,525 ; 22,422 ; 23,751$. 


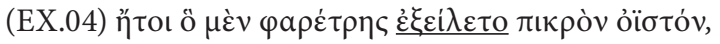

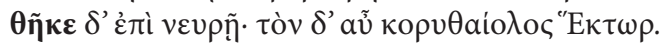

$$
\text { (Iliad 8,323-324) }
$$

'He took a sharp arrow from his quiver and put it on the bowstring, but then Hektor with the flashing helmet (hit) him.'

There are also instances in which the reduction rule seems to operate inversely, namely that an unaugmented form precedes an augmented one. ${ }^{13}$ One such instance is

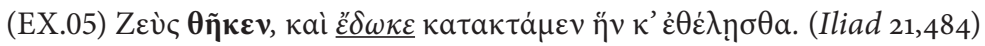

'(Since) Zeus had made you (to be a lioness among the women) and has given you the power to kill whomever you want.'

In this instance Hera attacks Artemis for siding with the Trojans and for having received the power to kill women at random by Zeus. The form $\theta \tilde{\eta} \kappa \varepsilon v$ is the first in the passage and is unaugmented, while $\varepsilon \delta \omega \kappa \varepsilon$ is augmented and follows the unaugmented form (the augment in this verb is of type $B$, but is nevertheless defendable because an unaugmented verb form would create a verse with a spondee in the first and second foot, and that is not so common: in the Iliadic corpus mentioned above, we have 945 instances out of 7483 verses, which is $13 \%$ ).

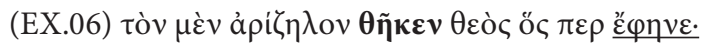

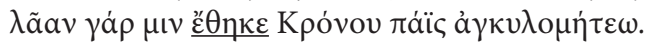

(Iliad 2,318-319)

'The god who had made him appear, made him very visible; the son of Kronos with the crooked mind then turned him into a stone.'

In this instance, one first has the unaugmented $\theta \tilde{\eta} \kappa \varepsilon v$, then the augmented $\varepsilon$ $\varphi \eta v \varepsilon$ and then again an augmented $\varepsilon \theta \eta \kappa \varepsilon$, although it is preceded by the augmented form $\varepsilon^{\prime} \varphi \eta v \varepsilon$.

\subsection{The position of the verb and the (direct) object: Verberststellung and OV-VO}

The next issue we have to address is if there is a clear connection between augment use and the position of the verb in the sentence or verse and the position of the (direct) object and the verb (the so-called OV or VO placement). When the verb appears at the beginning of the sentence, it is more often than not unaugmented (Chantraine 1948: 482; Kiparsky 1968: 41; Bertrand 2006a; De Lamberterie 2007: 37, 56-57; De Decker 2016a: 71-74). ${ }^{14}$ In PIE and in other old Indo-European languages such as Anatolian, Vedic Sanskrit and Greek, the sentence-final position

13 This observation was made by Levin (1969) and Lazzeroni (1977: 12-15) already, but they drew different conclusions from it, Levin agreed with Kiparsky while Lazzeroni did not.

14 Van Thiel (1991: xxvi) pointed out that this had been observed already by the Byzantine scholars. 
(Verbendstellung) was the default one (regardless whether one considers the verb in PIE to be enclitic or not)..$^{15}$ When the verb was thus put at the beginning of the sentence (Verberststellung), it already received emphasis by its position, ${ }^{16}$ and therefore did not need any additional focus by adding an augment. Mutatis mutandis the same can be said about verbs put in necessary enjambment, ${ }^{17}$ a feature that will be discussed later on. In the corpus under investigation here there is not a single augmented verb form that appears at the beginning of the sentence or verse. It has also been argued that verbs that are followed by their direct object tend to be much less augmented than verbs that are preceded by it (De Lamberterie 2007: 48-52; Rodeghiero 2017: 635-639). I cannot investigate here whether Homeric Greek had OV or VO word order, but I looked at books 1-2,483, 3-9 and 11-17 and found the following data describing the use of (un)augmented forms when used with OV or VO word order.

OV order

\begin{tabular}{|c|c|c|c|c|c|c|}
\hline & 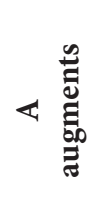 & 呈 & ४ & 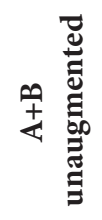 & 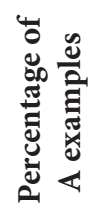 & 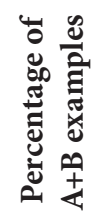 \\
\hline Speeches & 224 & 326 & 225 & 244 & 50 & 57 \\
\hline Narrative & 414 & 617 & 875 & 973 & 32 & 39 \\
\hline Speech introductions & 140 & 208 & 40 & 44 & 78 & 83 \\
\hline Overall figures & 778 & 1151 & 1140 & 1261 & 41 & 48 \\
\hline
\end{tabular}

15 That the verb final position was default was noticed before by Bergaigne (1877, 1879), Delbrück (1878: 17, 1888: 17), Kühner, Gerth (1904: 595), Watkins (1963: 48, 1998: 68), Kuryłowicz (1968: 72), Fortson (2010: 142-144), Fritz (2010: 384). The idea that the verb final position is the unmarked one and the initial one is marked, goes back to Delbrück (1878: 17-19). It was expanded to the languages discovered shortly before and after Delbrück's death by Dressler (1969). For PIE in general see Watkins (1963: 48), Fortson (2010: 142-144), Fritz (2010: 384), and for Hittite see also Luraghi (1990: 88-89, 110-117) and Bauer (2011).

16 For the common practice (almost a linguistic universal) to put the focalized element in sentence initial position, see Li, Thompson (1976: 465). The problem is that this applies to Hittite and Vedic Sanskrit, but not to Classical Greek. The default position of the verb in Classical Greek is neither sentence-final (Dik 1995, 2007) nor sentence-initial. Instances of Verberststellung (V1 in Dik's notation) in Classical Greek do not always involve new information: Schwyzer, Debrunner (1950: 693-695) argued that a sentence-initial verb links the action with what precedes and Dik (1995) stated that the sentence-initial position referred to something already known. She later modified her earlier research by stating that "all new-sentences are always verb-initial, but not all verb-initial sentences are all-new" (Dik 2007: 54). For epic Greek, the situation is not so clear-cut, because to the present day no in-depth investigation into the meaning of the sentence initial position of the finite verb form has been performed.

17 I use this term in the meaning that Parry (1929: 203) ascribed to it. 
VO order

\begin{tabular}{|c|c|c|c|c|c|}
\hline « & 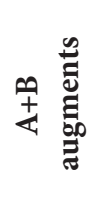 & « & 裉 & 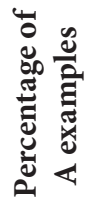 & 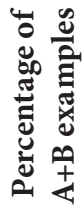 \\
\hline 67 & 95 & 118 & 130 & 36 & 42 \\
\hline 188 & 292 & 606 & 644 & 24 & 31 \\
\hline 8 & 12 & 13 & 17 & 38 & 41 \\
\hline 263 & 399 & 737 & 791 & 26 & 34 \\
\hline
\end{tabular}

The data show that an OV order has less unaugmented forms than VO and the corpus under investigation here confirms the connection between augment use/ absence and OV/VO word order: in the sentences with VO word order, we find that there are 12 unaugmented forms (of which 9 of the type $\mathrm{A}$ ) and 3 augmented ones (of which only 1 of type A), ${ }^{18}$ whereas the sentences with OV have 39 augmented forms (of which 32 of the type A) and 19 unaugmented forms (all type A).$^{19}$ I give an example of an augmented verb form with OV word order and an unaugmented verb with $\mathrm{VO}$ word order.

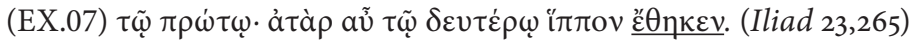

'(...) for the first one, but for the one finishing second he set (as price) a horse (...).'

In this instance the verb form $\varepsilon \theta \eta \kappa \varepsilon v$ appears at the end of the verse and is preceded

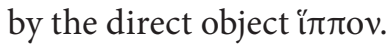

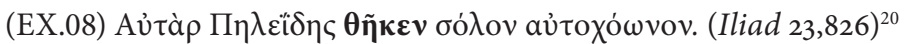

'But then the son of Peleus put (forward) a massive lump of iron.'

In this instance the unaugmented $\theta \tilde{\eta} \kappa \varepsilon v$ is followed by the direct object $\sigma$ ó $\lambda o v$ aủ toxówvov.

In fact, the clitic rule, the Verberststellung and the VO-OV distinction are (at least to a large extent, if not completely) faces of the same coin. When the verb appears

18 The unaugmented VO instances are Iliad 6,357; 8,218; 8,324; 9,460; 9,547 (type B); 12,399; 18,476; 23,269 (type B); 23,653; 23,700; 23,826; 24,538. The augmented VO instances are 6,482; 21,172 (type B); 21,524 (type B).

19 The unaugmented OV instances are Iliad 1,$55 ; 2,318 ; 2,482 ; 5,445 ; 6,303 ; 10,46 ; 10,571 ; 16,223$; 17,$541 ; 18,375 ; 21,145 ; 21,484 ; 23,153 ; 23,263 ; 23,748: 23,750 ; 23,799 ; 23,826 ; 23,886 ; 24,101$. The augmented OV instances are Iliad 1,2 (type B); 2,319; 3,321; 3,330; 3,336; 6,6; 6,139; 8,188; 9,207; 9,483; 10,257; 10,261; 10,466 (type B); 11,17; 12,450; 15,478; 15,480; 16,131; 16,137; 17,470; 17,569; 19,12 (type B); 19,369; 19,407 (type B); 20,324; 21,82; 21,525 (type B); 22,44; 22,368; 22,422 (type B); 23,$265 ; 23,270 ; 23,382 ; 23,400 ; 23,406 ; 23,527 ; 23,568 ; 23,704 ; 23,751$ (type B).

20 Surprisingly enough, the verse with an augmented verb and OV order would have been pos-

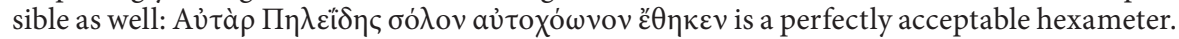


in the first position of the sentence, it becomes the focus of the statement, as it is not its normal position. It is, however, a tendency of clitics to attach themselves to words in focus (Janse 1993, 2014: 24-25). As such, it is only expected that they would seek the Wackernagel position after the first focused word of the sentence. The same applies to the VO word order: when the verb occupies the first position of the sentence, the object can only follow the verb.

\section{The analysis itself: The semantic criteria}

I now discuss the semantic observations on the augment and apply them to the corpus that has been established before.

\subsection{Foreground versus background}

The most important distinction that can be made about the use and absence of the augment is the distinction foreground/emphasis versus background. The augment is present when pivotal moments in the story or new elements are described, but is not used in actions that describe the background. In the Iliad dressing for battle is an important action (as is e.g. preparing an offering and a feast) ${ }^{21}$ and these actions are described with mostly augmented verb forms. In Book 23 both Patroklos and Hektor have already died, and the main elements of that book are the mistreatment of Hektor's body and the funerary games held in honour of Patroklos. The price setting for those games is one of the highlights, and the verbs involved in those descriptions are emphasized (either by the augment or by other features such as VO word order or enjambment, cf. infra).

One example is the following passage (as always, the unaugmented forms are put in bold face, the augmented ones are underlined and the forms that are metrically insecure are italicized; forms that are italicized and bold, are unaugmented forms of which the absence of the augment was established on the basis of internal comparison and forms that are italicized and underlined have an augment that was established on the basis of internal comparison):

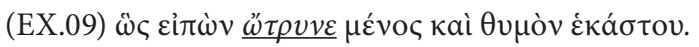

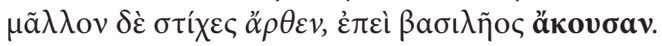

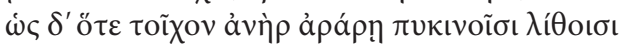

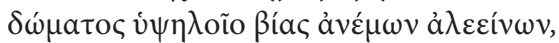

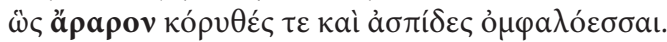

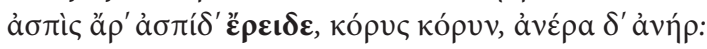

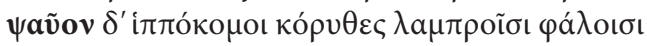

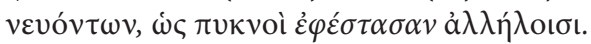

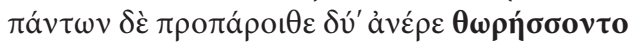

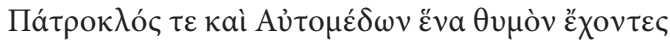

\footnotetext{
${ }^{21}$ For an analysis of the prototypical actions in the Iliad see Arend (1933).
} 


\begin{tabular}{|c|c|}
\hline 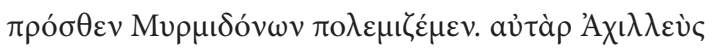 & $(220)$ \\
\hline 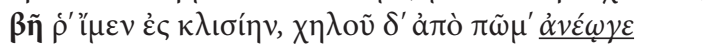 & $(221)$ \\
\hline 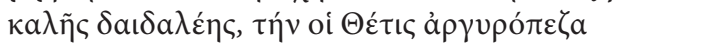 & $(222)$ \\
\hline 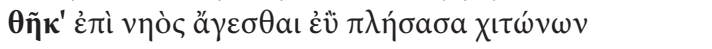 & $(223)$ \\
\hline 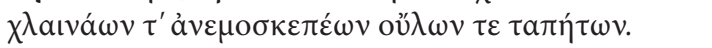 & $(224)$ \\
\hline 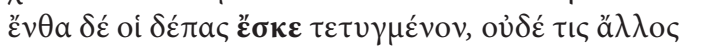 & $(225)$ \\
\hline 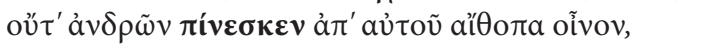 & $(226)$ \\
\hline 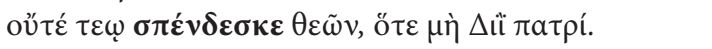 & $(227)$ \\
\hline 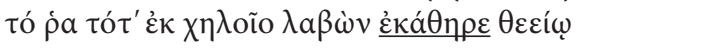 & $(228)$ \\
\hline 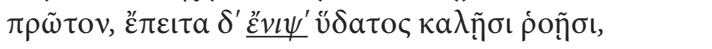 & $(229)$ \\
\hline 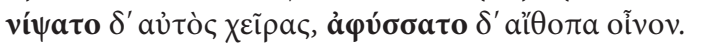 & $(230)$ \\
\hline 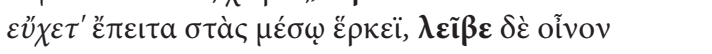 & $(231)$ \\
\hline 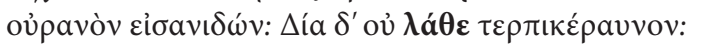 & \\
\hline
\end{tabular}

(Iliad 16,210-232)

'So he spoke and incited the power and spirit of each man. They put themselves in battalions, after they heard the king. As when a man assembles a wall with thick stones to keep off the violence of the winds of the high roof, so the helmets and hollow shields were assembled. Shield leaned on shield, helmet on helmet, man on man. The helmets with horse hair touched with the shining horns the people that were leaning. So close to each other they had put themselves. In front of all of them two men put on their armour, Patroklos and Automedon, who were of one spirit to fight in front of the Myrmidons. But Akhilleus entered the tent, opened the lid of a beautiful and well-wrought chest, that Thetis with the silver feet had put to be taken with him and had filled it well with tunics, mantles to keep out the winds and woollen carpets. Inside there was a wellwrought goblet, and no one else from the men would drink shining wine from it nor would he (sc. Akhilleus) pour a libation for any of the gods from it, except for father Zeus. He took the goblet out of the chest, cleaned it first with incense and washed it then with beautiful streams of water, washed his own hands and poured the shining wine into it. Standing in the middle of the enclosure he prayed, poured the wine and looked at the bright sky, and did not go unnoticed to Zeus who finds pleasure in the thunder.'

In this passage Homer describes how Akhilleus incited the Myrmidons to fight bravely under the guidance of Patroklos, who was about to enter the battle field disguised

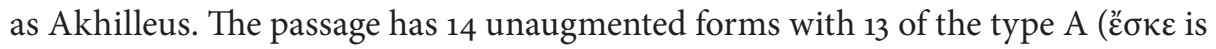
probably unaugmented because it has - $\sigma \kappa-$ in it, but as this form is not an original iterative, one cannot be sure) against 4 augmented ones with 1 of the type A ( $\ddot{\tau} \rho v v \varepsilon$ is probably augmented, because otherwise we have a spondee in the second foot with a second half foot long by position and not by nature, ảvé $\gamma_{\varepsilon \varepsilon}$ because it appears in verse final position and '̌v ${ }^{\prime} \psi^{\prime}$ because a violation of Nikanor-Meyer is more common

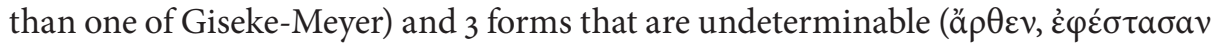
and $\varepsilon u_{\chi \varepsilon} \tau^{\prime}$ can be read with and without augment without violating any metrical rule): only the verbs referring to the preparation by Akhilleus of the offer and prayers to the gods to request a safe homecoming and success (namely $\dot{\varepsilon} \kappa a ́ \theta \eta \rho \varepsilon$ and हैvı $\psi^{\prime}$, but that augment is not entirely certain) have the augment. ${ }^{22}$ The fact that the audience

22 See for this passage also Mumm (2004: \$5.3). 
knows that this will be in vain adds a dramatic effect to the passage. The other actions referring to this procedure are placed in sentence initial position and are followed by a clitic, and have no augment because of that. The verb form $\theta \tilde{\eta} \kappa^{\prime}$ is unaugmented, because the action to which it refers does not belong to the main storyline: it appears in a subordinate clause and states that the coffer out of which Akhilleus is taking the gifts was given to him by his mother Thetis, but at that moment of the story the origin of the coffin has no importance and therefore the verb has no augment.

A special case of a "meal scene" is the following passage.

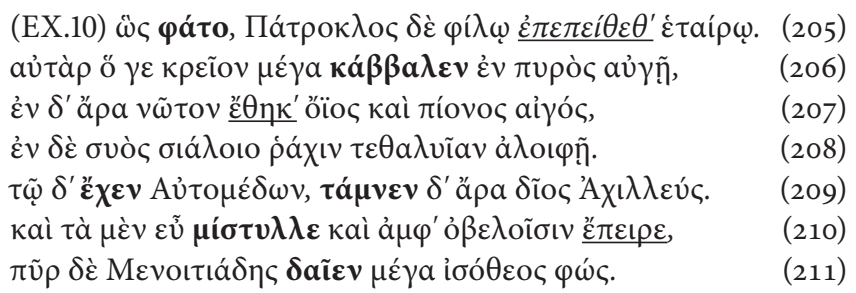

(Iliad 9,205-211)

'So he spoke and Patroklos obeyed his beloved comrade. Then he threw a large chopping block in the heat of the fire, placed the back of a sheep and a fat goat on it, and the chine of a fat hog, shining because of the oil. Automedon kept that for him, and shining Akhilleus divided (the pieces), cut them well into pieces and put them on a spit. The son of Menoitios, the great godlike hero, made the fire burn.'

In book 9 Agamemnon decides, adviced by Nestor, to send an embassy to Akhilleus begging him to return to the battle. The delegation is constituted by Phoinix, Aias and Odysseus, and the heralds Odios and Eurybates. When Akhilleus sees them approaching, he orders Patroklos to prepare a meal for them. This passage describes how Patroklos and Akhilleus prepare a meal for the Greek envoys. This description is peculiar in that it is the only instance in the Iliad in which a guest is offered meat from animals that had been slaughtered before (Arend 1933: 69). The unusual meal preparation (sc. putting already prepared meat on the fire) therefore starts with an augmented verb form.

Several other distinctions have been suggested in the literature and will be discussed below, but even within those distinctions, the deciding factor remains the presence/absence of emphasis and foreground.

\subsection{Speeches versus narrative passages}

It has been noted before that narrative passage have much less augmented forms than the speeches (Koch 1868; Platt 1891: 223; Monro 1891: 62; Drewitt 1912a; Chantraine 1948: 484; Bottin 1969: 110-128; Basset 1989; West 1989; Bakker 1999, 2005: 114-153; Mumm 2004; De Decker 2016b: 289-291, 2017: 96, 136-137). In this corpus, there are 15 forms that appear in a speech: 10 are augmented (of which 8 of type $A)^{23}$

23 The augmented instances in speeches are Iliad 2,319; 3,321; 6,139; 9,483; 17,470; 22,44; 22,422 (type B); 23,333 (type B); 23,406; 24,531. 
and 5 are not (of which 4 of type $\mathrm{A}$ - the exceptions will be discussed later on). ${ }^{24}$ The figures confirm the preference for augmented forms in speeches, but they do not show that the augmented forms abound in speeches and are completely missing in narrative. The augment use in speeches and narrative is also dependent on other factors: in speeches without a clear connection to the present or in sentences that relate something unimportant, the augment is not used. This has been noted before for the speeches by Nestor in Iliad 1 and by Glaukos and Diomedes in Iliad $6 .{ }^{25}$ I give one example from a speech:

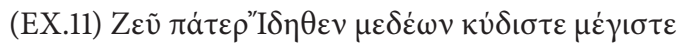

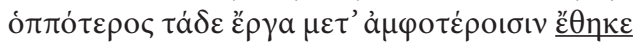

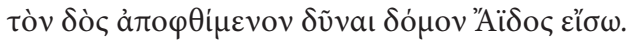

$$
\text { (Iliad 3,320-322) }
$$

'Father Zeus, most honourable and greatest guardian, from the Ida, give that the one from the both of them who has put the misery on both of us may be killed and go down to the House of Hades.'

This passage is taken from the duel in Book 3 where Menelaos and Paris will decide in a single fight who will have Helen as his wife. When the duel is announced, undefined Trojans and Greeks alike pray and ask Zeus to punish the responsible for the Trojan War. The form $\varepsilon \forall \eta \kappa \varepsilon$ is augmented because it appears in a speech and clearly refers to the present situation, namely the duel at hand. The augment use is therefore not solely "speech-based", but can also be explained by the fact that the action described by $\varepsilon^{\prime} \theta \eta \kappa \varepsilon$ is very near and present for the audience (the duel is occurring before their eyes and they are living with the consequences of the marital conflict between Paris and Menelaos).

\subsection{New versus old}

The augment is used in verb forms that emphasize an event and/or communicate something surprising or a new element in an enumeration of events (Mumm 2004; De Decker 2016a: 81-84). This can be combined with the previous and following points: as speeches often communicate something that is important for the speaker and sometimes unknown to the hearer, the use of the augment in speeches is expected; also in narrative, certain actions can be highlighted (although there are several instances in which the augment appears without a clear reason). This is especially the case for the descriptions of warriors gearing up and dressing for battle. Such a typical passage can be found in:

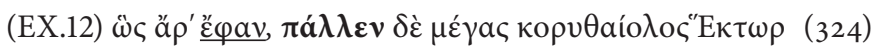

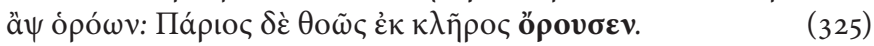

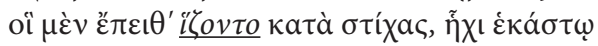

24 The unaugmented instances are Iliad 2,318; 9,460; 10,46; 21,484; 24,538 (type B).

25 Already Koch (1868: 27-28) noted that speeches could have narrative elements, and he pointed at Nestor's speech in Iliad 1 specifically; see also Monro (1891: 62), Chantraine (1948: 484), Basset (1989: 14) and De Decker (2017: 136-138) for Iliad 1. 


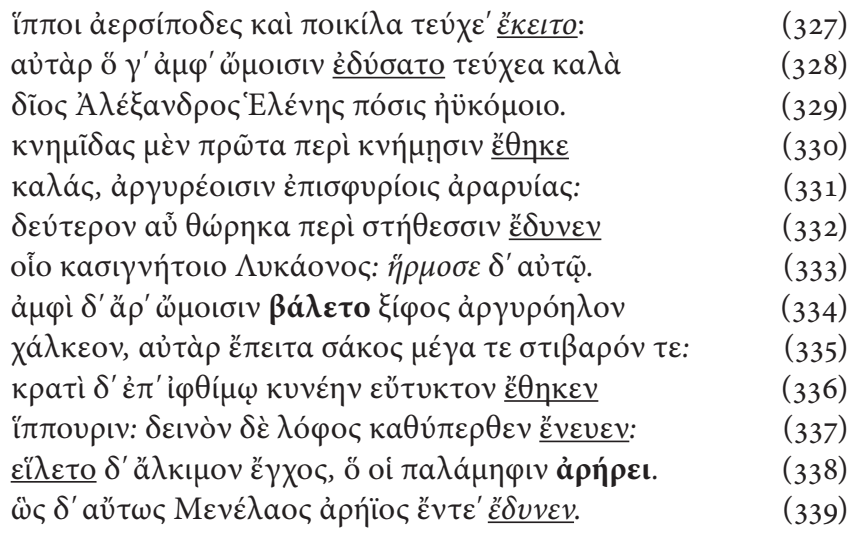

(Iliad 3,326-339)

'So they spoke. Hektor with the shining helmet looked away and drew lots. Quickly Paris's lot jumped out (of the box). They (sc. the armies) set themselves in rows, where each man's high stepping horses and their bright armour stood. But then shining Alexandros, husband of Helen with the beautiful hair, put on his beautiful armour around his shoulders, placed his beautiful greaves around his legs, assembled out of beautiful ankle pieces. Second, he put the corselet of his brother Lykaon over his chest and fitted it on himself. Around his shoulders he threw the bronze silverstudded sword, and then his big and sturdy shield. He then put his well-wrought helmet with horse hair on his strong head. Terribly, the crest nodded from above. He then took his famous sword, that fitted in his palms. And warlike Menelaos put on his weaponry in the same way. ${ }^{26}$

This passage describes how Hektor draws lots to see who can throw his javelin first in the duel between Menelaos and Paris, and how both warriors proceed to putting on their armour and preparing for the duel. Battle preparations and putting on armour are typical scenes in Homer and such descriptions are often highlighted (Arend 1933: 92-98). As such, the augment is used to describe the individual steps (as can be seen in the underlined forms). ${ }^{27}$ The unaugmented form $\pi \alpha$ a $\lambda \lambda \varepsilon v$ does not have an augment, because it appears in sentence-initial position and is followed by a clitic; the form ảpń $\rho \varepsilon$ is unaugmented because it appears in a subordinate sentence and does not belong to the act of dressing itself. There are two unaugmented forms that surprise: first, ôpov $\sigma \varepsilon v$, because announcing who is allowed to throw his spear first, is not a mere descriptive element, but an important advantage in the battle, and second, the unaugmented $\beta a ́ \lambda \varepsilon \tau o$. The form $\varepsilon_{\varphi} \varphi \alpha v$ has a metrically secure augment, because monosyllables are avoided before pauses, caesurae and at $6 \mathrm{~b} .{ }^{28}$ The forms

26 This translation is based on Murray, Wyatt (1999: 152).

27 See also Rodeghiero (2017: 631-632).

28 I was unable to find out which scholar had first stated this bridge, but Bekker (1863: 148) noted that very few verses had a sixth foot that ended in a monosyllabic word. Before him, Hermann (1817: 216) had already observed that a word end there was dispreferred, but not excluded, when special emphasis was needed. Hoffmann (1842: 20-21) catalogued this caesura among the caesurae minores, but stated that a caesura in this position was possible, if something 


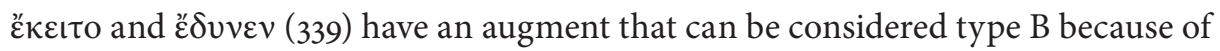

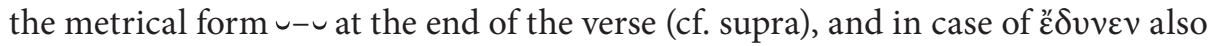

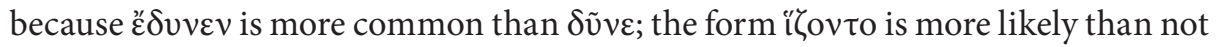
augmented, because if it is not augmented, the second foot would have a spondee with a second half foot long by position, and this is, though not impossible, still much less common. ${ }^{29}$ The augment in

The same applies to the similar passages, such as Iliad 11,15-20 and 16,130-139.

These passages can serve as evidence that Kiparsky's reduction rule was not a mechanic syntactic law of Homeric Greek.

\subsection{Recent versus remote/mythical past}

Scholars have observed that the augment is used, when actions in a recent past are described or when a past action still has relevance for the present, ${ }^{30}$ and that it tends to be absent when actions in a remote or mythical past are described. ${ }^{31}$ This has been linked with the use of the augment in sentences with the adverb viv $v$, as this refers to an action in the immediate past (Platt 1891; Drewitt 1912a: 44; Bottin 1969: 87-89, 135-136; Bakker 1999: 53, 60-62; García Ramón 2012: F1b; De Decker 2015b: 289, 315, 2016a: 289). The corpus has four examples of an augmented verb and the adverb vivv, of which three are metrically secure and one is undeterminable. ${ }^{32}$ I first give two examples of the augment use in an action in the recent past.

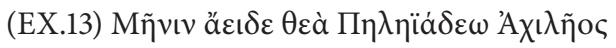

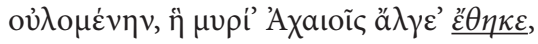

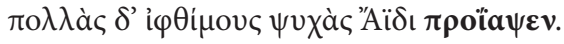

(Iliad 1,1-3)

'Sing, goddess, about the wrath of Akhilleus, son of Peleus, a deadly one that brought sorrows to countless Akhaians and threw many strong souls down into the Hades.'

These are the opening lines of the poem and they clearly refer to something that in the mind of the poet has just happened and an event that will dominate the poem. ${ }^{33}$

spectacular was announced or if the poet spoke about Zeus. Meyer (1884: 983) noted that the combination of a dactylic word and a monosyllabic word before the caesura in the third foot was avoided. See also Meister (1921: 6), Sjölund (1938: 63), Snell (1982: 16), Barnes (1986: 141) and Sicking (1993: 81), who argued that a monosyllabon at the end of a sentence, colon or verse was not preferred.

29 I refer to the corpus of 7483 verses mentioned above: there are 779 verses with a spondee in the second foot with a second half foot long by position, this is $10 \%$.

30 Platt (1891) used the term "perfect aorist" to describe these forms. See also Drewitt (1912a, 1912b, 1913), Bakker (1999, 2002, 2005).

31 For Homer, see already Platt (1891) and Drewitt (1912a, 1912b). Hoffmann (1967: 16o-213) noted the use of the injunctive in contexts that he described as "fernere nicht historische Vergangenheit". See also Strunk (1968) and Euler (1995).

32 Iliad 17,470, 21,82 and 23,406 are secure; 23,333 is undeterminable.

33 For more details on this passage see De Decker (2017: 148-149). 




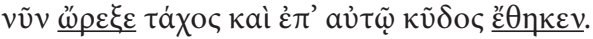

(Iliad 23,405-406)

'(I am not ordering you to compete) with the horses of the battle-minded son of Tydeus, to them Athene has now endowed with speed and to the man she has given honour.'

In this passage during the funerary games for Patroklos, Antilokhos shouts to his horses that they should be brave but should not try to compete with Diomedes's horses since Athene has just given them strength. As Antilokhos is referring to events that are happening at this very moment, the augment is used in $\omega \rho \varepsilon \xi \varepsilon$ and $\varepsilon^{\prime} \theta \eta \kappa \varepsilon v$. As the verbs refer to two different aspects (the speed of the horses and the honour of Diomedes), the reduction rule has not operated and both $\omega \rho \varepsilon \xi \varepsilon$ and

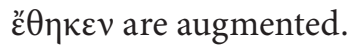

Rather than a mere distinction recent versus remote past, I believe that the examples are more indicative of the distinction foreground-background. In the corpus under investigation, there are only two instances that refer to a remote past and in one of them an augmented form is used and in another one, an unaugmented form. While two forms are too little to make a decisive judgement, the augment use in the passages does in fact confirm what has been stated above.

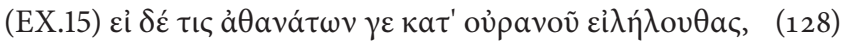

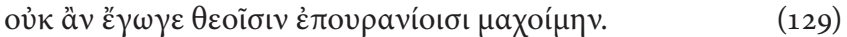

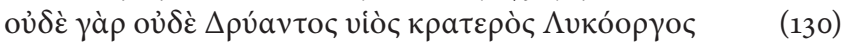

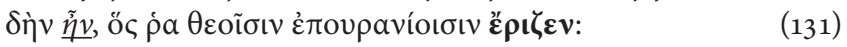

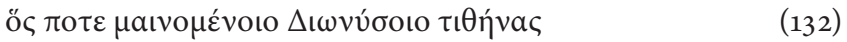

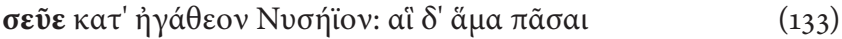

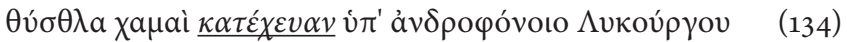

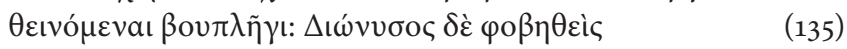

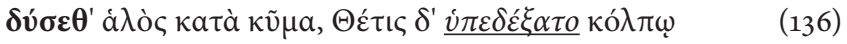

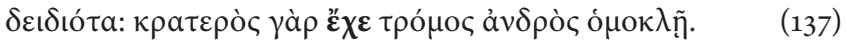

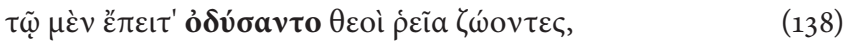

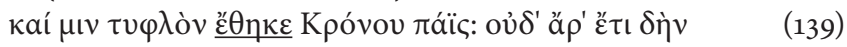

ĩv

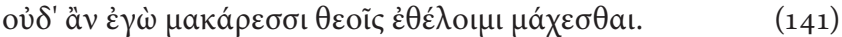

(Iliad 6,128-141)

'If you are one of the immortals and have come from heaven, I would not fight against the gods in heaven. For the son of Dryas, the strong Lykourgos did not live long, he who fought with the heavenly gods and once stormed against the nurses of the raging Dionysos through the holy Nysean hill. Together they shattered their offerings on the ground, hit with an ox-goad by the manslaying Lykourgos. Struck with fear Dionysos hid himself under the wave of the sea and Thetis covered him, fearful, in her bosom. The strong shivering held him because of the threatening shouts of the man. Him (L) hated then all the gods who live in all easiness and blind made him the son of Kronos and he did not live much longer, since he was hated by all the gods. I therefore would not want to fight the blessed gods.' 
In this passage Diomedes addresses Glaukos and asks him if he is a god; if he is, he will not fight him, because it is very unwise to challenge and upset the immortals. In order to prove his story, he relates the mythical story of Lykourgos who was so hated by the gods that Zeus struck him with blindness. In spite of the story belonging to the mythical past, the verb has an augment. This can be explained by the fact that the divine punishment is highlighted here and serves as a deterrent in Diomedes's mind.

\begin{tabular}{|c|c|}
\hline 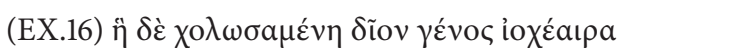 & $(538)$ \\
\hline 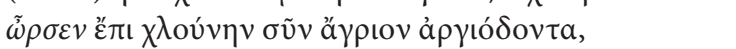 & (539) \\
\hline 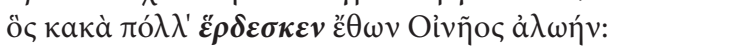 & $(540)$ \\
\hline 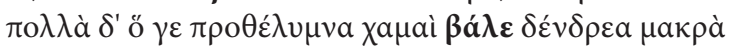 & 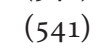 \\
\hline 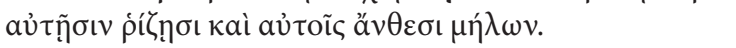 & 2) \\
\hline 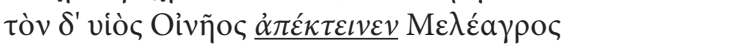 & \\
\hline 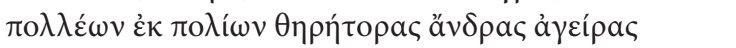 & $(5$ \\
\hline 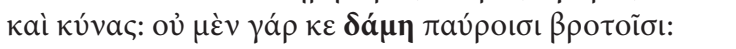 & $(545)$ \\
\hline 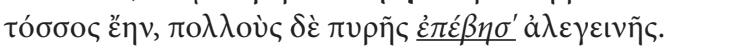 & 6) \\
\hline 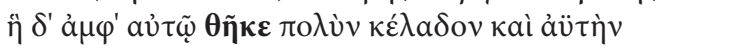 & \\
\hline & \\
\hline 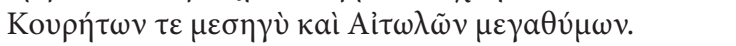 & \\
\hline
\end{tabular}

(Iliad 9,538-549)

\begin{abstract}
'The goddess that shoots arrows, the divine offspring, grew angry at that and sent against them a fierce wild boar with sharp teeth, that caused much havoc at his will to the orchard of Oineus. Many high trees he uprooted and threw to the ground with their roots and even with the fruits of the apple trees themselves. The son Oineus, Meleagros, killed it after he had gathered many hunters and dogs from many cities, since it would not have been tamed by a few men, so big was it and many it drove into the painful pyre. But the goddess incited over him, over the head and the hairy skin of the boar, much battle noise and war-cry in the middle between the Kouretes and the great hearted Aitolians.'
\end{abstract}

In this passage Phoinix tells Akhilleus that his stubborn refusal to save the Akhaians might turn him into a second Meleagros, who also refused to help his fellow countrymen out of personal resentment and only intervened when the houses next to his own were already burning. The example here is taken from a passage that describes how Artemis was angered with Meleagros's city and sent a wild boar that caused destruction and panic, but that the city remained safe as long as Meleagros was willing to protect it. In the middle of the story, however, Phoinix alludes to the reason why Meleagros became angry with his fellow countrymen (but he does not tell the story entirely): the boar that Meleagros killed, caused a rift between him and his mother's brothers. He killed them, his mother cursed him and he withdrew from battle. The reason why he withdrew from battle is less pivotal to the story (just as the reason why Akhilleus is angry is of lesser importance to Phoinix as well, he just wants his friend to return to battle and save the Greeks), hence its being narrated only partially. The form $\theta \tilde{\eta} \kappa \varepsilon$ has no augment, not because it appears in a remote story, but because it has no foregrounded value in this remote story. 


\subsection{Gnomic aorists}

A special instance of foregrounding is the Homeric use of the augment in general truths and proverbs: they describe a general truth the knowledge of which is based on past experiences and refer to past actions of which the correctness is still valid at the moment of speaking or to actions that occurred in the past, but could (re)occur at any time in the present. ${ }^{34}$ Such actions and descriptions mostly, if not always, illustrate and confirm what the speakers or poets are saying, so almost by definition they are foregrounded and emphasized. In the entire Iliad I counted 23 augmented gnomic aorists (of which 16 were of the type A) and 5 unaugmented ( 4 of type A). ${ }^{35}$ This shows that the augment is overwhelmingly preferred in the gnomic aorist, but not absolutely mandatory either.

There is only one example in the corpus we are investigating here:

(EX.17) $\tilde{\omega} \delta \dot{\varepsilon} \kappa \varepsilon \tau \tilde{\omega} v \lambda v \gamma \rho \tilde{\omega} v \delta \omega \dot{\eta}, \lambda \omega \beta \eta \tau o ̀ v \underline{\varepsilon} \theta \eta \kappa \varepsilon$. (Iliad 24,531)

'To whom he gives from the jar of pains, him he makes a failure.'

This verse belongs to Akhilleus's speech to Priam after he $(\mathrm{P})$ came to his tent to beg for the release of Hektor's dead body. Akhilleus explains to Priam that the gods bestow good and evil upon mankind. This verse states that the man who receives from Zeus out of the jar of evils will turn into a failure; as this is a general truth, $\varepsilon \theta \eta \kappa \varepsilon$ is augmented. This statement is clearly foregrounded by Akhilleus, because he wants to show to Priam (and to himself) that absolute happiness does not exist and all mortals have to carry their burdens.

34 The literature on the gnomic aorist is large, but I cannot address the issue here. That the gnomic aorist was almost always augmented in Homer, had been noticed very early on: Platt (1891), Herbig (1896: 250-270), Delbrück (1897: 302), Wackernagel (1904: 5, 1920: 181), Brugmann (1916: 11 , who noted that there was no explanation for this fact; this goes against his earlier explanation of 1890: 185 and 1892: 1276-1277 that in origin the gnomic aorist was unaugmented and acquired its augment only when the augment became more and more established in Greek epic diction), Drewitt (1912a, 1912b, 1913), Hirt (1928: 171-173). See more recent: Pagniello (2002: 74-84), Bakker (2001: 18-23, 2005: 131-135), Faulkner (2005: 68-69), Bertrand (2006b: 241), De Decker (2016a: 55-67, 87-90, 2017: 92, 140-141).

35 The unaugmented instances are Iliad 4,320, 9,320, 11,28, 24,49.

Other exceptions are Odyssey 8,481,14,465 (an instance of àvĩ $\varepsilon \varepsilon$ ), 17,271; Theogony 447 (the absence of the augment is not secured by the metre in that specific instance), Works and Days 17-20 (if the aorists in this passage are indeed gnomic), 345, 702-705, 740-741 (cf. De Decker 2016a: 55-67).

In Iliad 17,99 both $\pi \tilde{\eta} \mu \alpha \kappa v \lambda$ í $\sigma \theta \eta$ and $\pi \tilde{\eta} \mu^{\prime} \varepsilon \dot{\varepsilon} \kappa \nu \lambda i ́ \sigma \theta \eta$ are transmitted (the augmented form occurs in only one papyrus). Platt (1891: 219, writing before the papyrus was available) suggested to read the augmented form. It is difficult to decide which variant to choose, as the augmented one could be defended by the simile-nature of the passage and the unaugmented form, because it makes the verse end in $\backsim-\cup$.

Iliad 14,382 is in my opinion not a gnomic aorist, but describes the distribution of the weaponry according to the nature of the individual fighter and does not convey any notion of general truth. 


\subsection{Homeric similia}

Closely related to the use of the augment in the gnomic aorist, is its use in the similia, the Homeric comparisons in which Homer compared a battle scene or another event to a scene from everyday life (mostly in the agricultural sphere) (Platt 1891; Drewitt 1912a, 1912b, 1913; Chantraine 1948: 484; Shipp 1972: 120; Bakker 1999: 64, 2002: 75-77, 2005: 114, 121, 131-134). As the similes compare an action in the recent past with occurrences in the past, and "they are 'close' to the audience, in evoking a domestic rather than heroic, reality" (Bakker 1999: 64, 2005: 114), their link with the present and the audience is evident and the use of the augment therefore does not surprise, ${ }^{36}$ but as was the case with the gnomic aorist, the use of the augment in the similia is not absolute: in the Iliad there are 113 augmented instances (of which 82 of type A) and 13 unaugmented instances (of which 11 A type forms). ${ }^{37}$

In this corpus, there is one example:

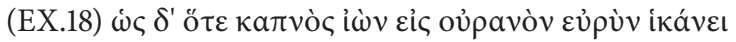

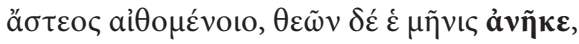

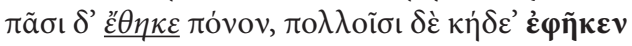

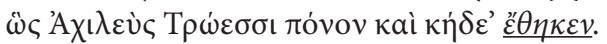

$$
\text { (Iliad 21,522-525) }
$$

'As when smoke from a burning city goes up into the broad sky, the anger of the gods has been set loose on it and puts toil on all of them and throws sorrows on many of them. In that way Akhilleus created pain and sorrow for the Trojans.'

In this passage Akhilleus causes so much death and destruction among the Trojans that his fury is compared to a god who is enraged with a certain city and decided to lay her waste. The augment in $\varepsilon^{\prime} \theta \eta \kappa \varepsilon(524)$ is insecure (cf. supra), but the fact that it

36 Bakker (2005: 114, 121, 131-134), Shipp (1972: 120) stated that "(the augment use) illustrates the linguistic similarity of proverbial comments and similes".

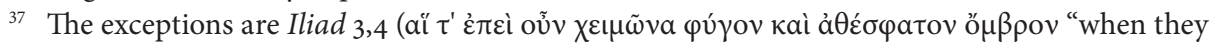
were fleeing winter and the unheavenly rain", where the constraint against an elision at the caesura guarantees the unaugmented form, against Bakker (2001: 8-9) who considered this instance to be insecure because he thought that the augment could be added in the text even if it meant having a caesura with an elision), 4,75 (of type B), 4,279, 4,483 (the absence of the augment is guaranteed by Tiedke-Meyer's Law, cf. Part I of the article), 5,770, 15,682 (the absence of the augment is guaranteed by Hermann's Bridge and even Platt (1891: 219) hesitated in adding the augment here, although several codices have the augmented form),16,633, 16,634 (unless one interprets them with Janko (1992: 391-392) as presents and not as pluperfects and imperfects), 21,523, 21,524, 23,223 (where Platt (1891: 220) argued that the metre prevented the poet from using the augmented form, which is true but does not explain why he did not use an augmented alternative), 23,432 (which is, as 21,523 and 21,524 an instance of $\tilde{\eta} \kappa-$ and - $\tilde{\eta} \kappa-$ - cf. infra).

The observation made for the unaugmented gnomic aorist in 17,99 applies to the verb

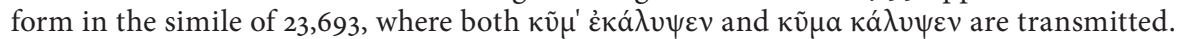
As was the case in 17,99, the unaugmented form seems to be supported by the verse end in $u-u$, whereas the simile-nature of the passage would lend its support to the augmented form. The difference between 17,99 and 23,693 is that in the former the augmented form is found in only one papyrus, whereas in the latter several codices have the augmented form. Given that the gnomic aorist and the similia are generally augmented, it might be advisory to catalogue the forms as type B augments. 
appears in a simile, makes it more likely that the augmented form is the right one. The form $\varepsilon \theta \eta \kappa \varepsilon v$ (525) does not belong to the simile anymore but makes the description return to the actual event. Remarkable are the two unaugmented forms, àvĩ $\kappa \varepsilon$ and $\dot{\varepsilon} \varphi \tilde{\eta} \kappa \varepsilon v$. In his analysis of the augment, Platt (1891: 218-219, 234-235) argued that the simplex and compound forms in $\eta^{\tilde{\eta}} \kappa-$ and - $\tilde{\eta} \kappa-$ might very well have been augmented after all. As $\tilde{\varepsilon} \eta \kappa-$ and $\tilde{\eta} \kappa-$ exist both and the augmented form can be ancient (from ${ }^{*} e-y e h_{1}$ ), it is in my opinion more likely that the forms in $\tilde{\eta} \kappa-$ and $-\tilde{\eta} \kappa-$ were actually unaugmented..$^{38}$ In that case, the unaugmented forms are exceptions to the rule that the similia were always augmented.

\section{Conclusion}

The investigation of the forms in the Iliad showed that the use and absence of the augment in $\varepsilon \ddot{\eta} \eta \kappa(\varepsilon)(v)$ and $\theta \tilde{\eta} \kappa(\varepsilon)(v)$ are not metrically motivated, but can be explained by an interaction of syntactic and semantic factors. I found that more than any other explanation the distinction foreground/emphasis versus background could explain the augment use most adequately: regardless whether used in a speech, a narrative description, subordinate or negative sentence, the verb form was augmented when the speakers and/or poets wanted to highlight certain aspects of their statements (e.g. when warriors dress for battle). As the Homeric similia and the gnomic aorists refer directly to the speakers' and hearers' worlds, they are by definition foregrounded, hence the predominant augment use in those contexts. The augment was not needed when the verb had received its emphasis by another means already, e.g. an enjambment, a sentence-initial position or an VO word order. I also found that Kiparsky's reduction rule was only operative if the verb forms described the same action.

\section{References}

\section{Online sources}

Chicago Homer: http://homer.library.northwestern.edu/html/application.html Thesaurus Linguae Graecae: http://stephanus.tlg.uci.edu

\section{Printed sources}

Arend W. 1933. Die typischen Scenen bei Homer. Berlin.

Bakker E. 1999. Pointing to the past: Verbal augment and temporal deixis in Homer. - Kazazis J., Rengakos A. (eds.). Euphrosyne. Studies in Ancient Epic and its Legacy in Honor of Dimitris. N. Maronitis. Stuttgart: 50-65.

38 See also Monro (1891: 60) and Chantraine (1948: 481). The forms were listed, but the issue was not addressed in neither Veitch (1879: 330-331), Kühner, Blass (1892: 203-204) nor Chantraine et al. (2009: 441-442).

If Peters (1976), followed by LIV²: 225, is right in reconstructing ${ }^{\star} h_{1} i h_{1}$ or ${ }^{\star} H_{i e h}$, the original augmented form would have been ${ }^{*} \eta \eta \kappa \varepsilon$. Peters's argument was that the long I in Attic ï $\mu$ เ could only be explained by a reduplicated form ${ }^{\star} h_{1} i-h_{1} i e h_{1}$ - $m i$ (via ${ }^{\star} \bar{j} j \bar{e} m i$ the form would have evolved into ${ }^{\star} \bar{h} \bar{e} m i$ and then into hiēmi or in Greek script ï $\left.\mu \mathrm{t}\right)$. 
Bakker E. 2001. Similes, augment and the language of immediacy. - Watson J. Speaking volumes. Orality \& literacy in the Greek \& Roman world. Leiden: 1-23.

Bakker E. 2002. Remembering the God's arrival. - Arethusa 35: 63-81.

Bakker E. 2005. Pointing at the past: From formula to performance in Homeric poetics. Cambridge (MA).

Barnes H. 1986. The colometric structure of the Homeric hexameter. - GRBS 27: 125-150.

Basset L. 1989. L'augment et la distinction discours/récit dans l'Iliade et l'Odyssée. - Casevitz M. (ed.). Études homériques. Lyon: 9-16.

Bauer A. 2011. Verberststellung im Hethitischen. - Krisch T., Lindner T. (eds.). Indogermanistik und Linguistik im Dialog. Wiesbaden: 39-48.

Beck W. 1919. De augmenti apud Homerum usu. Giessen.

Bekker I. 1863. Homerische Blätter. [Erster Band. Beilage zu dessen Carmina Homerica]. Bonn.

Bergaigne A. 1877. Essai sur la construction grammaticale considérée dans son développement historique. Paris.

Bergaigne A. 1879. Essai sur la construction grammaticale. - MSL 3: 1-51.

Bertrand N. 2006a. La localisation des formes intransitives d' $i \sigma \tau \eta \mu$. Le rôle de ع̌ $\sigma \tau \eta$ et $\sigma \tau \alpha \dot{~} \varsigma$ dans le récit homérique. - GAIA 10: 47-96.

Bertrand N. 2006b. Présence du passé dans l'épopée homérique. À propos de Pointing to the past de EJ Bakker. - GAIA 10: 237-243.

Blumenthal H. 1974. Some Homeric evidence for the history of the augment. - IF 79: 67-77.

Bottin L. 1969. Studio dell'aumento in Omero. - SMEA 10: 69-145.

Brugmann K. 1890. Griechische Grammatik. München.

Brugmann K. 1892. Grundriß der vergleichenden Grammatik der indogermanischen Sprachen. [vol. 2.2]. Strassburg.

Brugmann K. 1916. Grundriß der vergleichenden Grammatik der indogermanischen Sprachen. [vol. 2.3]. Strassburg.

Chantraine P. 1948. Grammaire homérique. Paris.

Chantraine P., Masson O., Perpillou J., Taillardat J. 2009. Dictionnaire étymologique de la langue grecque. Paris.

Clackson J. 2007. Indo-European linguistics: An Introduction. Cambridge.

Clausen W. 1955. Silva Coniecturarum. - AJP 76: 47-62.

Corbett G. 2000. Number. Cambridge.

Cysouw M. 2011. The expression of person and number: A typologist's perspective. - Morphology 21: 419-443.

De Decker F. 2015a. The augment in Homer, with special attention to speech introductions and conclusions. - De Decker F., Jakob K., Klumm M., Kunzmann M., Lindbüchl I., Stoll T. (eds.). JournaLIPP 4 Proceedings of the $21^{\text {st }}$ LIPP Symposium: 53-71. [https://lipp. ub.lmu.de/index.php/lipp/article/view/4841/2723].

De Decker F. 2015b. A morphosyntactic analysis of speech introductions and conclusions in Homer. [PhD Thesis LMU München; https://edoc.ub.uni-muenchen.de/17995/].

De Decker F. 2016a. A contrastive analysis of the Homeric and Hesiodic augment, with special focus on Hesiod. - IJDL 13: 33-128.

De Decker F. 2016b. The augment use in Iliad 6: An evidential marker? - LEC 58: 259-317.

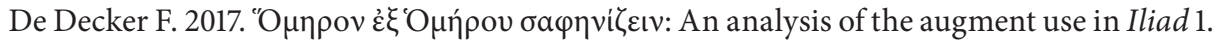
- JIES 45: 58-171.

De Decker F. 2020. Metrical and morphological observations on the use of $\ddot{\varepsilon} \theta \eta \kappa \varepsilon(v)$ and $\theta \tilde{\eta} \kappa \varepsilon(v)$ in the Iliad. - Studia Linguistica Universitatis Iagellonicae Cracoviensis 137.1: 67-81.

De Lamberterie C. 2007. L'augment dans le texte arménien de l'Évangile. - REArm 30: 31-57.

Delbrück B. 1878. Syntaktische Forschungen III. Die Altindische Wortfolge aus der Çatapathabrāhmana. Halle. 
Delbrück B. 1888. Syntaktische Forschungen V. Altindische Syntax. Halle.

Delbrück B. 1897. Vergleichende Syntax der indogermanischen Sprachen II. Strassburg.

Dik H. 1995. Word order in Ancient Greek. Amsterdam.

Dik H. 2007. Word order in Greek tragic dialogue. Oxford.

Dressler W. 1969. Eine textsyntaktische Regel der idg. Wortstellung. - KZ 83: 1-25.

Drewitt J. 1912a. The augment in Homer. - CQ 6: 44-59.

Drewitt J. 1912b. The augment in Homer (continued). - CQ 6: 104-120.

Drewitt J. 1913. A note on the augment. - CP 8: 349-353.

Dubois L. 1986. Recherches sur le dialecte arcadien. [3 vols]. Louvain-la-Neuve.

Dunkel G. 1978. Preverb deletion in Indo-European? - KZ 92: 14-26.

Euler W. 1995. Der Injunktiv, die archaischste Verbalkategorie im Indogermanischen. Smoczyński W. (ed.). Kuryłowicz Memorial Volume. Part One. Cracow: 137-142.

Faulkner A. 2005. Aphrodite's aorists: Attributive sections in the Homeric hymns. - Glotta 81: $60-79$.

Fortson B. 2004. Indo-European language and culture: An introduction. Oxford.

Fortson B. 2010. Indo-European language and culture: An introduction. [ $2^{\text {nd }}$ edition]. Oxford.

Fritz M. 2010. Indogermanische Syntax. - Meier-Brügger M. (ed.). Indogermanische Sprachwissenschaft. Berlin: 374-412.

Fritz M. 2011. Der Dual im Indogermanischen. Heidelberg.

García-Ramón J. 2012. TAM, augment and evidentiality in Indo-European. [Handout from the Workshop Grammatische und lexikalische Strukturen im Wandel held in Cologne, March 21 - 23.2012].

Hajnal I. 1990. Die mykenische Verbalform e-e-to. - MSS 51: 21-75.

Hajnal I. 2016a. Induktive versus abductive Rekonstruktion: das Beispiel des griechischen Augments. [Handout from the Workshop in Honour of M. Job on March 2 in Göttingen].

Hajnal I. 2016b. Induktive versus abduktive Rekonstruktion: das Beispiel des griechischen Augments. - IF 121: 435-453.

Herbig G. 1896. Aktionsart und Zeitstufe. - IF 6: 157-270.

Hermann G. 1817. Elementa Doctrinae Metricae. London.

Hirt H. 1928. Indogermanische Grammatik IV. Doppelung, Zusammensetzung, Verbum. Heidelberg.

Hoffmann C. 1842. Quaestiones Homericae. Clausthal.

Hoffmann K. 1967. Der Injunktiv im Veda. Heidelberg.

Janko R. 1992. The Iliad: A commentary. [vols 13-16]. Cambridge.

Janse M. 1993. The prosodic basic of Wackernagel's law. - Crochetière A., Boulanger J., Ouellon C. (eds.). Les langues menacées: Actes du XVe Congrès international des linguistes. Sainte-Foy (QC): 19-22.

Janse M. 2014. Inleiding tot de Homerische taal en metriek. Gent.

Kiparsky P. 1968. Tense and mood in Indo-European syntax. - FL 4: 30-57.

Kiparsky P. 2005. The Vedic injunctive: Historical and synchronic implications. - Singh R. (ed.). The yearbook of South Asian languages and linguistics: 219-235. [accessed online: www.degruyter.com/view/book/9783110186192/10.1515/9783110186185.219.xml].

Kloekhorst A. 2017. The Old Hittite and the Proto-Indo-European tense-aspect system. - IF 122: 295-307.

Koch K. 1868. De augmento apud Homerum omisso. Braunschweig.

Kühner R., Blass F. 1892. Griechische Grammatik. Formenlehre. [vol. 2]. Hannover.

Kühner R., Gerth B. 1904. Ausführliche Grammatik der griechischen Sprache. Zweiter Theil. Satzlehre. [vol. 2]. Hannover. 
Kuryłowicz J. 1968. Indogermanische Grammatik. II Akzent. Ablaut. Heidelberg.

Lazzeroni R. 1977. Fra glottogonia e storia: ingiuntivo, aumento e lingua poetica indoeuropeo. - SSL 17: 1-30.

Levin S. 1969. Remarks on the 'historical' present and comparable phenomena of syntax. FL 5: 386-390.

Li C., Thompson S. 1976. Subject and topic: A new typology of language. - Li C. (ed.). Subject and topic. New York: 457-489.

$\mathrm{LIV}^{2}=\mathrm{Rix}$ H. (ed). 2001. Lexikon der indogermanischen Verben. Wiesbaden.

Luraghi S. 1990. Old Hittite sentence structure. London.

Luraghi S. 2014. Conjunction reduction. - Giannakis G. (ed.). The encyclopaedia of Ancient Greek language and linguistics. Leiden: 362-363.

Marzullo B. 1952. Il problema omerico. Firenze.

Meillet A. 1913. Altarmenisches Elementarbuch. Heidelberg.

Meister K. 1921. Die homerische Kunstsprache. Leipzig.

Meyer W. 1884. Zur Geschichte des griechischen und des lateinischen Hexameters. - SBAW 4: 979-1089.

Monro D. 1891. A grammar of the Homeric dialect. Oxford.

Moravcsik E. 2017. Number. - Aikhenvald A., Dixon R. 2017 (eds.). The Cambridge handbook of linguistic typology. Cambridge: 440-476.

Mumm P. 2004. Zur Funktion des homerischen Augments. - Krisch T. (ed.). Analecta homini universali dicata. [Festschrift für Oswald Panagl]. Stuttgart: 148-158.

Murray A., Wyatt W. 1999. Homer Iliad. Books 1-12. Cambridge (MA).

Pagniello F. 2002. The augment in Homer. [PhD Thesis, University of Georgia at Atlanta].

Patri S. 2007. Remarque sur le positionnement syntaxique du déterminant adverbial (préverbe) en indo-européen. - IF 112: 26-38.

Parry M. 1929. The distinctive character of enjambement in Homeric verse. - TAPA 60: 200-220.

Peters M. 1976. Attisch híemi. - Die Sprache 22: 157-161.

Platt A. 1891. The augment in Homer. - JPh 19: 211-237.

Rodeghiero S. 2017. L'aumento in Omero tra narrazione e sintassi. - Logozzo F., Poccetti P. (eds.). Ancient Greek linguistics. New approaches, insights and perspectives. Berlin: 625-640.

Rosén H. 1973. Satzbau und augmentloses Tempus in Homerischen Tatsachenbericht. FoL 6: 315-330.

Schwyzer E., Debrunner A. 1950. Griechische Grammatik. Teil II. Syntax. München.

Shipp G. 1972. Studies in the language of Homer. Cambridge.

Sicking C. 1993. Griechische Verslehre. München.

Sjölund R. 1938. Metrische Kürzung im Griechischen. Uppsala.

Snell B. 1982. Griechische Metrik. Göttingen.

Strunk K. 1968. Zeit und Tempus in den altindogermanischen Sprachen. - IF 73: 279-311.

Strunk K. 1975. Zum Verhältnis von Wort und Satz in der Syntax des Lateinischen und Griechischen. - Gymnasium 82: 225-239.

Szemerényi O. 1990. Einführung in die vergleichende Sprachwissenschaft. Darmstadt.

Szemerényi O. 1996. Introduction to Indo-European linguistics. Oxford.

Van Thiel H. 1991. Homeri Odyssea. Hildesheim.

Veitch W. 1879. Greek verbs. Defective and irregular. Oxford.

Viti C. 2011. The use of the dual number in Homer. - Krisch T., Lindner T. (eds.). Indogermanistik und Linguistik im Dialog. Wiesbaden: 595-604. 
Wackernagel J. 1904. Studien zum griechischen Perfektum. Göttingen.

Wackernagel J. 1920. Vorlesungen über Syntax. I. Basel.

Wackernagel J. 1924. Vorlesungen über Syntax. II. Basel.

Watkins C. 1963. Preliminaries to a historical and comparative analysis of the syntax of the Old Irish verb. - Celtica 6: 1-49.

Watkins C. 1967. An Indo-European construction in Greek and Latin. - HSCP 71: 115-119.

Watkins C. 1998. Proto-Indo-European: Comparison and reconstruction. - Giacalone Ramat A., Ramat P. (eds.). The Indo-European languages. London: 25-73.

West M. 1989. An unrecognized injunctive usage in Greek. - Glotta 67: 135-138. 